\title{
List of Medieval Religious Houses on Islands: Ireland
}

The first survey of Island Monasteries in Ireland dates back to 1891 when George T. Stokes, Irish ecclesiastical historian published results of field trips to "Island Monasteries in Wales and Ireland" in the Journal of the Royal Society of Antiquaries of Ireland. ${ }^{1}$ Inspired by Gabriela Signori, host of this International conference on the monastic island of Reichenau at Lake Constance in January 2017, the plan to provide an up-to-date survey took shape. Of course we expected a significant number of island monasteries in Ireland, itself famous as "Isle of the Saints" (Lisa Bitel). ${ }^{2}$ Thus the research project was started with great expectations. However, the results amply exceeded all expectations by far: Over 100 monastic islands in Ireland could be identified so far. The first results of this research project are presented here in the conference proceedings as an annotated "List of Medieval Religious Houses on Islands in Ireland".

At the end of the $19^{\text {th }}$ century George T. Stokes could draw his initial data from the monumental Monasticon Hibernicum, a work compiled in the $18^{\text {th }}$ century by Mervyn Archdall (1723-1791). ${ }^{3}$ Archdall was an antiquarian who spent forty years of his life documenting over 550 pre-Reformation monasteries in Ireland. Since then, in the mid $2^{\text {th }}$ century the Jesuit historian Aubrey Gwynn, President of the Royal Irish Academy and Historian at University College Dublin, promoted research towards a new Monasticon Hibernicum and a Map of Monastic Ireland. The plan was realized with some delay in 1970, mainly executed by his co-author R. Neville Hadcock, who together with David Knowles had already mastered the Medieval Religious Houses in England and Wales and another volume on Scotland. The Medieval Religious Houses in Ireland comprises over 1000 monastic sites. ${ }^{4}$

More recently the Monasticon Hibernicum found thorough revision and enlargement. From 2003 to 2007 Ailbhe MacShamhráin together with Nora White and Aidan Breen under the direction of Kim R. McCone prepared an

\footnotetext{
1 Stokes, Island Monasteries, p. 661.

2 Bitel, Isle of the Saints, p. 37.

3 Archdall, Monasticon Hibernicum.

4 Gwynn/Hadcock, Medieval Religious Houses.
} 
online database of pre-twelfth century ecclesiastical settlements in Ireland. The database counts a total of 5529 sites, names of remains of monasteries, churches, church yards, cathedrals, hermitages, and proprietary churches, also including at least 412 which are presently unindentifiable. As the authors make clear in their foreword their database supplies an 'ecclesiasticon' rather than a 'monasticon' and it remains a matter for debate how many of the sites recorded were indeed community foundations. However, this database is an excellent up-to-date working tool to identify even remote and otherwise obscure sites. Published as an open access resource by the Dublin Institute of Advanced Studies it can be consulted free of charge by scholars from all over the world. ${ }^{5}$ The following list (Annexe 1) relies mainly on the data supplied by Gwynn and Hadcock (abbreviated GH) collated with the date from Monasticon Hibernicum (abbreviated MH). The later is to be searched by place names or keywords. Therefore, no page numbers are indicated here. Additional on-site information was also drawn from the online database on Early Christian Sites in Ireland by Father John Musther. ${ }^{6}$

The islands are numbered from 1-103, starting in Ulster in the North, over Leinster in the East to Munster in the South and from their back North via Connacht in the West (map 1).?

$\begin{array}{ll}\text { Ulster } & \text { Munster } \\ \text { Down (1-3) } & \text { Waterford (38) } \\ \text { Antrim (4,6) } & \text { Cork (39-43) } \\ \text { Derry (5) } & \text { Kerry (44-57) } \\ \text { Donegal (7-9) } & \text { Limerick (60) } \\ \text { Fermanagh (10-20) } & \text { Clare (58, 59, 61-70) } \\ \text { Monaghan (21) } & \text { Connacht } \\ \text { Cavan (22-24) } & \text { Galway (71-89) } \\ & \text { Mayo (90-98) } \\ \text { Leinster } & \text { Roscommon (99, 100) } \\ \text { Meath (25) } & \text { Sligo (101-103). } \\ \text { Longford (26-8) } & \\ \text { Westmeath (29-32) } & \\ \text { Dublin (33-35) } & \\ \text { Wexford (36-7) } & \end{array}$

5 Monasticon Hibernicum.

6 Musther, Early Christian Sites.

7 I would like to express my thanks to Sophia Rishyna, Jonathan Trautmann and Hannah Mechler for their invaluable help with the maps and graphs. The maps are based on QGIS Geographic Information, Version 2.18.3. 
A total of 103 monastic islands have been identified. 52 houses are located on sea islands, most of them in the West, a total of 27 off the Galway/Mayo coast and 14 off the Iveragh Peninsula, Kerry. Only three sea island monasteries were found on the East Coast, in the Irish Sea: St Patrick's Island, Lambay Island, and Ireland's Eye. Of the 51 island monasteries in inland waters, more than half are situated in the North. The Fermanagh region with Upper and Lower Lough Erne appears to have been an El Dorado for monks. 12 island communities round Upper and Lower Lough Erne could be traced (9-20). Another cluster of can be found in the River Shannon and its lakes: In the Shannon Estuary these are Scattery Island, Canon Island, Inishmore (Deer Island), Carrig Island, Inishloinge, Feenish, and Inishloe (57-64). Further up in Lough Derg, one of the lakes of the River Shannon there are three island monasteries: Inishcaltra (Holy Island), Mucinis, and Illaunmore (66-69), and again further upstream we have Hare Island, Saints Island, Inchbofin, and Inchcleraun (29-31). Five inland water monasteries are located in Mayo, in Lough Corrib and Lough Mask: Inchiquin (74), Inishmicatreer (75), Illan Columbkille (92), Church Island (94), and Partry (93). As regions with the highest density of island monasteries one can identify: 1. The West Coast, Counties Galway and Mayo, 2. The Counties Kerry and Clare, and 3. The region around Upper and Lower Lough Erne in County Fermanagh.

Catharine Thom recently pointed out that many of the Irish monasteries are near-water-sites. She named Bangor at the Southern shore of Belfast Lough, Clonmacnoise at the shores of the Shannon or Glendalough in the Wicklow Hills with its upper and lower lake. ${ }^{8}$ Even though coastal and nearwater-sites might have had a similar function as insular sites the list above does not include them. Thus, famous coast side and near water foundations in the Northeast, Belfast Bay such as Bangor, Holywood or Grey Abbey in Strongford Lough are missing in the list. Also the list does not include the three monastic sites on the Mullet in County Mayo (the early sites Termoncarragh and St Derivla's and the Augustinian Canons in Cross), the houses on Achill Island in Mayo, Valentia island in Kerry, the four houses or churches on the Peninsula of Islandmagee (Ballykeel, Cell Chiannáin, Cell Chluana, Killcoan), and Ballysaggart in Donegal Bay.

It is very important to remember that landscapes do change over the centuries! The list of Medieval Religious Houses on Islands in Ireland can

8 Tном, Early Irish Monasticism, p. 17. 


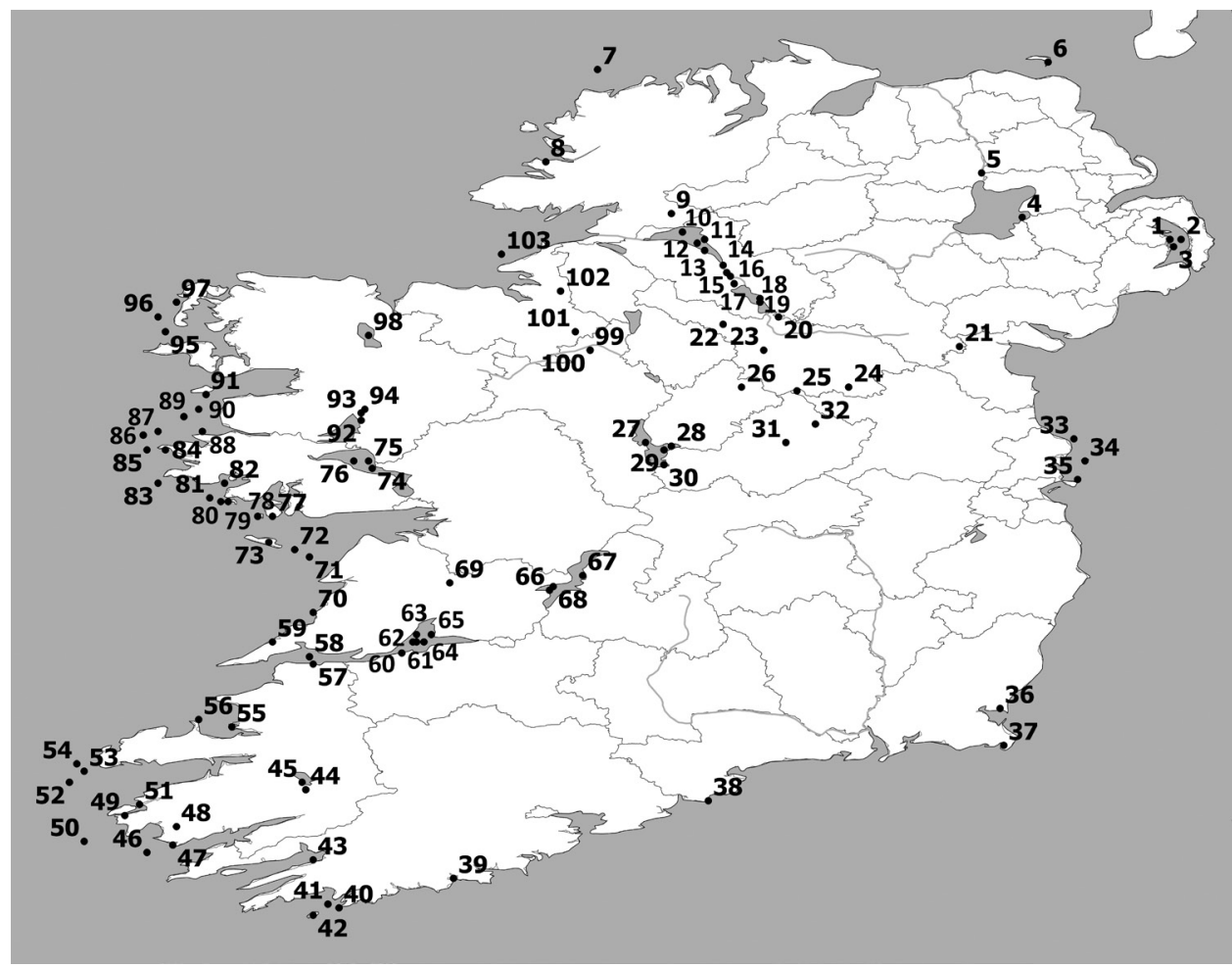

Map 1. Medieval Religious Houses on Islands in Ireland 


\begin{tabular}{ll}
1 & Nendrum \\
2 & Chapel Island \\
3 & Dunsy \\
4 & Rams Island \\
5 & Church Island \\
6 & Rathlin \\
7 & Tory \\
8 & Inishkeel \\
9 & Saints Island \\
10 & Boa Island \\
11 & White Island \\
12 & Davy's Island \\
13 & Inishmacsaint \\
14 & Devenish \\
15 & Rossory \\
16 & Inishkeen \\
17 & Cleenish \\
18 & Iniseo? \\
19 & Magheracross \\
20 & Galloon \\
21 & Inishkeen \\
22 & Mogue's Island \\
23 & Trinity Island \\
24 & Woodworths Island \\
25 & Lough Sheelin \\
26 & Inchmore \\
27 & Inchcleraun \\
28 & Saints Island \\
29 & Inchbofin \\
30 & Hare \\
31 & Church Island \\
32 & Nuns Island \\
33 & Saggart \\
34 & Lambay \\
35 & Ireland’s Eye \\
& \\
\hline
\end{tabular}

$\begin{array}{ll}36 & \text { Beggerin } \\ 37 & \text { Ladys Island } \\ 38 & \text { Ardmore? } \\ 39 & \text { Inchydoney } \\ 40 & \text { Sherkin } \\ 41 & \text { Skeam } \\ 42 & \text { Cape Clear } \\ 43 & \text { Whiddy Island } \\ 44 & \text { Dinish } \\ 45 & \text { Innisfallen } \\ 46 & \text { Scariff } \\ 47 & \text { Derrynane } \\ 48 & \text { Church Island } \\ 49 & \text { Illaunloughan } \\ 50 & \text { Skellig Michael } \\ 51 & \text { Church Island } \\ 52 & \text { Inishvickillane } \\ 53 & \text { Great Blasket } \\ 54 & \text { Inishtooskert } \\ 55 & \text { Fenit } \\ 56 & \text { Illauntannig } \\ 57 & \text { Carrig } \\ 58 & \text { Scattery } \\ 59 & \text { Bishop’s Island } \\ 60 & \text { Inishloinge } \\ 61 & \text { Canon } \\ 62 & \text { Inis-tuaischert } \\ 63 & \text { Inishmore } \\ 64 & \text { Inishloe } \\ 65 & \text { Feenish } \\ 66 & \text { Inishcaltra } \\ 67 & \text { Illaunmore } \\ 68 & \text { Mucinis } \\ 69 & \text { Inchicronan } \\ 70 & \text { Enniskerry } \\ & \\ \end{array}$

36 Beggerin

38 Ardmore?

39 Inchydoney

40 Sherkin

41 Skeam

42 Cape Clear

43 Whiddy Island

44 Dinish

45 Innisfallen

46 Scariff

47 Derrynane

48 Church Island

49 Illaunloughan

50 Skellig Michael

51 Church Island

Inishvickillane

55 Fenit

56 Illauntannig

57 Carrig

58 Scattery

59 Bishop's Island

60 Inishloinge

61 Canon

62 Inis-tuaischert

63 Inishmore

64 Inishloe

65 Feenish

66 Inishcaltra

67 Illaunmore

69 Inchicronan

70 Enniskerry
71 Aran Inisheer

72 Aran Inishmaan

73 Aran Inishmore

74 Inchiquin

75 Inishmicatreer

76 Inchagoil

77 Gorumna

78 Kilcummin

79 Mason

80 Macdaras Island

81 Croaghnakeela

82 Inishnee

83 Chapel Island

84 Omey

85 High Island

86 Inishark

87 Inishbofin

88 Crump

89 Inishturk

90 Caher

91 Clare

92 Illan Columbkille

93 Partry

94 Church Island

95 Duvillaun More

96 Inishkea North

97 Inishglora

98 Errew

99 Trinity

100 Inchmacnerin

101 Inishmore

102 Church Island

103 Inishmurray 
only give a description of the present-day situation. One has to bear in mind that status quo in the early $21^{\text {st }}$ century does not represent the situation in the Middle Ages. Nature and settlement patterns do change. The cultivation of land was certainly less intensive in the middle ages than today. Most of Ireland was wooded. Heavy deforestation, especially since the $16^{\text {th }}$ century onwards, changed the landscape significantly. Water levels also rise and fall. The following examples speak for themselves: The islands of Lough Erne must have been much smaller in medieval times, before the Lough was lowered by eight feet (2,5 meters) in 1884 to assist with drainage, particularly in Upper Lough Erne where winter flooding was a real problem for agriculture. ${ }^{9}$ Boa Island, now a peninsula was certainly an island at the time. Also Rossory, now on the banks of Lough Erne might have been an island, at the time when St Fanchae founded her monastery there (15). The same applies for Inishkeen (16), now also on the shores of the lake.

Amongst other monastic islands that lost their insular position over the course of time is Ardmore, alias Sheep Island in Waterford, probably the oldest monastic island in Ireland. In pre-patrician times it was used as pasture for the sheep belonging to the wife of the chieftain of the local kings of the Decies. Later it must have been joined to the mainland by reclamation or draining of the channel at the time when the vita of Declan was compiled in the late $10^{\text {th }}$ century. According to Declans hagiographer, the saint performed the miracle of the expulsion of the sea, thus joining Sheep Island to the mainland. ${ }^{10}$ Possibly Inishkeen (Inish Cam) in Monaghan, four miles north-west of the church of Louth, founded by St Daig in the $6^{\text {th }}$ century used to be an island. Today, it is a near water site, but it seems quite plausible, that the river had more water and that Inishkeen was a river island once. ${ }^{11}$

Other islands might have been larger in medieval times. The water level of Lough Derg in Clare seems to have been much lower before a power station at Ardnacrusha was built in the 1920s. Thus, the extension of the monastic sites on Inishcaltra, alias Holy Island, Illaunmore and Mucinis in Lough Ree might have been larger than today. This is indicated by the present location of one of the bullaun stones on Inishcaltra about 5 meters out from the shore in the water. Clearly an indication, that this island lost land to the lake. ${ }^{12}$

9 Chambers, White Island, p. 14.

10 Power, Life of Declan, p. 19-20.

11 Kehnel, Clonmacnois, p. 77-79.

12 Madden, Holy Island, p. 9. 
Another example: The rock of Skellig Michael is a living system, puffins inhabited the rock much longer than humans, stones fall loose, and rocks have been breaking over the centuries and still break off today. Furthermore, intensive restoration works changed the sites. Especially much of the undocumented efforts of archaeologists and antiquarians in the $19^{\text {th }}$ century have often caused intense alterations and distortions. A quay and a lighthouse were built on Skellig Michael to make better use of the place for navigation. ${ }^{13}$ John Crowley has recently pointed to the fact that the whole of Valentia island on the slopes of Bray - with its corbelled huts, some of which feature crosses inscribed on their walls within an extensive area of old cultivation ridges - may have functioned as Skellig Michael's monastic farm. ${ }^{14}$

Similarly, the ring fort structures of many island monasteries pre-date Christian times. In their present shape they represent the result of intensive - often undocumented - reconstruction works by $19^{\text {th }}$ and $20^{\text {th }}$ century historians and antiquarians. This applies to the famous constructions on Inish Murray as well as to Fort Eoghan on Aranmore or to the stone figures of White Island. Many of the seemingly early medieval beehive cells and round towers are in fact the work of dedicated $19^{\text {th }}$ century antiquarian and local initiatives. And of course, all the buildings have been changed continuously ever since the very time they were built. ${ }^{15}$

Despite the fact that many of the Irish monastic islands are well documented, and that excavation reports do offer precise descriptions, it is not always easy to give the exact sizes of the islands. Tides and weather, for example, can cause the islands to vary in size. The smallest island is probably Illaunloughan (49) in the harbour of Portmagee, Kerry, where the ships to Skellig Michael leave. It measures less than an acre, has the approximate size of the Library Square in Trinity College Dublin and is situated about 100 metres off the main land. Apparently, it can be reached by foot during some days in the summer month. Despite the minimal size, the monastic remains are impressive and have been excavated and documented by Jenny White Marshall and Claire Walsh in 2003. ${ }^{16}$ Church Island in Lough Cur-

13 Horn/White Marshall/Rourke, Forgotten Hermitage, p. 8.

14 Crowley, Valentia Island, in: Crowley/Sheehan/Murphey, The Iveragh Peninsula, p. 260.

15 White Marshall/Rourke, The secular origins, p. 34; Cotter, Western Stone Forts, Sec. 11; Chambers, White Island, p. 29. The last of the figures on White Island was discovered in 1958 by a member of Enniskillen Field Club.

16 White Marshall/Walsh, Unpublished Excavations Report 12.6. 
rane (48) is the second smallest monastic Island. It measures about one acre (or $4046 \mathrm{~m}^{2}=0.004 \mathrm{~km}^{2}$ ), followed by Chapel Island in Galway (83) with a rounded size of $0.047 \mathrm{~km}^{2}$. With the exception of the two Church Islands (in Kerry and Galway) and Dunsy Island in Down (3), all small islands are sea islands. Four of them are situated in the Shannon Estuary. Below, we listed the 16 monastic islands smaller than $0.5 \mathrm{~km}^{2} .^{17}$

\begin{tabular}{|l|l|}
\hline Illaunloughan, near Portmagee, Kerry & $.003 \mathrm{~km}^{2}$ \\
\hline Church Island in Lough Currane, Kerry & $.004 \mathrm{~km}^{2}$ \\
\hline Chapel Island off Clifden Bay, Galway & $.047 \mathrm{~km}^{2}$ \\
\hline Skeam Island West, Cork & $.12 \mathrm{~km}^{2}$ \\
\hline Dunsy Island, Strangford Lough, Down & $.13 \mathrm{~km}^{2}$ \\
\hline Illauntannig off Dingle, Kerry & $.13 \mathrm{~km}^{2}$ \\
\hline Inishglora off the Mullet, Mayo & $.15 \mathrm{~km}^{2}$ \\
\hline Ireland's Eye, near Dublin & $.22 \mathrm{~km}^{2}$ \\
\hline Skellig Michael, Kerry & $.22 \mathrm{~km}^{2}$ \\
\hline St Macdara's Island, near Carra, Galway & $.25 \mathrm{~km}^{2}$ \\
\hline Crump Island, north of Tully, Galway & $.26 \mathrm{~km}^{2}$ \\
\hline High Island, south of Inishbofin, Galway & $.33 \mathrm{~km}^{2}$ \\
\hline Inishkeel, north of Portnoo, Donegal & $.33 \mathrm{~km}^{2}$ \\
\hline Mason Island, near Carra, Galway & $.37 \mathrm{~km}^{2}$ \\
\hline Dinish Island, off Kenmare, Kerry & $.38 \mathrm{~km}^{2}$ \\
\hline Devenish Island in Lough Erne, Fermanagh & $.49 \mathrm{~km}^{2}$ \\
\hline
\end{tabular}

Table 1. The Irish Monastic Islands, today smaller than $0.5 \mathrm{~km}^{2}$

The largest monastic island with an area of $31 \mathrm{~km}^{2}$ is Inishmore of the Aran Islands (73), where Enda founded his school in the $7^{\text {th }}$ century. The second largest is Gorumna (77), also in Galway with nearly $24 \mathrm{~km}^{2}$. The list below gives the 14 monastic islands larger than two square kilometers, six of them being larger than ten square kilometers.

\begin{tabular}{|l|l|}
\hline Inishmore, Aran, Galway & $31 \mathrm{~km}^{2}$ \\
\hline Gorumna, Galway & $23.76 \mathrm{~km}^{2}$ \\
\hline Clare Island, Mayo & $16.4 \mathrm{~km}^{2}$ \\
\hline Rathlin Island, Antrim & $14.37 \mathrm{~km}^{2}$ \\
\hline Inishbofin, Galway & $12.75 \mathrm{~km}^{2}$ \\
\hline
\end{tabular}

17 Acres have been converted to square kilometers and rounded. Small Rounding errors or irregularities are therefore possible. 


\begin{tabular}{|l|l|}
\hline Inishturk, Mayo & $12.5 \mathrm{~km}^{2}$ \\
\hline Inishmaan, Aran, Galway & $9.11 \mathrm{~km}^{2}$ \\
\hline Cape Clear, Cork & $6.7 \mathrm{~km}^{2}$ \\
\hline Inisheer, Aran, Galway & $5.67 \mathrm{~km}^{2}$ \\
\hline Sherkin, Cork & $5 \mathrm{~km}^{2}$ \\
\hline Great Blasket, Kerry & $4.3 \mathrm{~km}^{2}$ \\
\hline Inishnee, Galway & $3.46 \mathrm{~km}^{2}$ \\
\hline Tory Island, Donegal & $3.18 \mathrm{~km}^{2}$ \\
\hline Lambay Island, Dublin & $2.5 \mathrm{~km}^{2}$ \\
\hline
\end{tabular}

Table 2. Monastic Islands in Ireland, today larger than two square kilometres

By far the largest part of the Irish island monasteries were founded prior to the $12^{\text {th }}$ century. According to Gwynn's and Hadcock's categories they are either "Early Irish Monasteries (E)" or "Early Sites, possibly non-monastic, but before 1100 (e)" ${ }^{18}$ Most of the later orders made use of older foundations and built their houses on ancient sites. For example, Devenish was founded by St Molaise in the $6^{\text {th }}$ century, Augustinian Canons arrived on the island in 1130 .

More than half, 57 island monasteries, seem to have $5^{\text {th }}$ and $6^{\text {th }}$ century origins, according to the presumed date of their respective founders' deaths. Three possible pre-Patrician island foundations can be made out: Ardmore in Waterford (38), which might have been an island in the Early Middle Ages, Beggerin Island (Becc Ériu, 36), near Slob Channel founded by Ibar, who is said to have been in Lérins prior to his career in Ireland. Inchbofin (29) in Lough Ree in Westmeath is said to have been founded by Rioch in the late $5^{\text {th }}$ century. Another 20 monastic island founders are dated by tradition to the $7^{\text {th }}$ and $8^{\text {th }}$ centuries.

Island foundations from the $12^{\text {th }}$ century onwards are rare: The Augustinian Canons settled in 16 island monasteries, all of them former early Irish Monasteries: Davy's Island (12) and Devenish (14), Errew (98), Inishkeen (21), Innisfallen (45) and Canon Island, alias Island of the Saints (61), in the Shannon Estuary and Inchicronan (69), Woodworths Island (24) in Lough Ramor, Inchmore (26) and Saints Island in Lough Ree (28), Saints Island near St Patrick's Purgatory in Lough Derg (9), Inchmacnerin (100) and Inchagoill (76). If one includes White Island (11), for which the sources are unclear,

18 Gwynn/Hadcock, Medieval Religious Houses, p. 20-46, 370-409. 
there are at least 17 houses of Augustinian Canons on islands. Certainly future research will add more. The Cistercians settled on Clare Island (91) in the $13^{\text {th }}$ century. A Franciscan Observant Friary was founded on Sherkin Island (40) in the late $15^{\text {th }}$ century. Interestingly there are no indications in the sources for the foundations of island monasteries in the time from the $9^{\text {th }}$ to the end of the $11^{\text {th }}$ century (table 3 ).

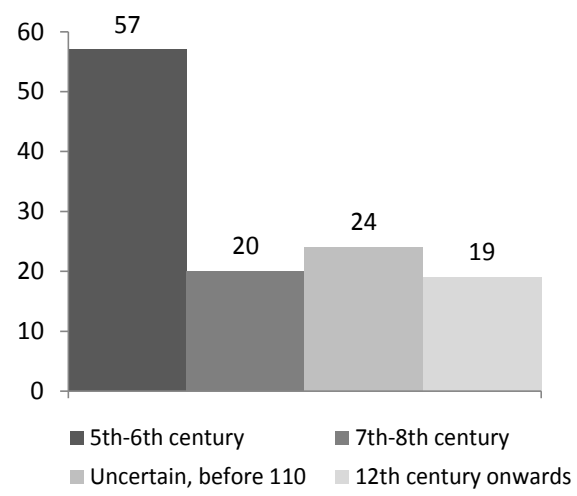

Table 3. Monastic Island sorted by founding date

The majority of the island monasteries were male houses. For 31 houses in our list, though, we found some connections with female communities or saints, be it a nuns' church on the premises or hagiographical links like in Rossory, where the sister of St Enda is said to have brought about his conversion (map 2). According to John Musther, Nun's Island in Lough Ree is said to have been settled "by some Poor Clares"19. However, the name of a place can be misleading, as the example of Lady's Island (37) shows. This was a church dedicated to the Virgin Mary and a pilgrims site, but never a monastery. Gwynn and Hadcock mention that St Daig, the $6^{\text {th }}$ century founder of Inishkeen (21) in the river Fane, attracted women and that many virgins came to live under his rule, but that he removed them to monasteries of their own to the north. ${ }^{20}$ Likewise the existence of buildings named after or dedicated to female saints does of course not necessarily prove the existence of nuns in an island monastery. For example, in the case of Inishmurray (64)

19 Musther, Early Christian Sites, Nun's Island.

20 Gwynn/Hadcock, Medieval Religious Houses, p. 37, cf. Kehnel, Clonmacnois, p. $77 \mathrm{f}$. 
we have a "Teampall na mBan" meaning "Church of the Women", but no further evidence for a female community. ${ }^{21}$ Often female presence within the monastic sites becomes apparent only in a post mortem state: The churches served as holy ground where women, men and children were buried. Over the course of excavations lead by Francoise Henry in the early 1970s on Inishcaltra on Lough Derg (66) more than 20 bodies were found deposited in the interior of St Brigid's Church. Amongst them were two women who died in childbirth (map 2).22

This first screening of the 103 Irish monastic island foundations that could be identified so far will hopefully add to future advances in the field of Monastic Island Studies by supplying a body of material to work with. The list will, it is hoped, have served a useful purpose if it contributes, in some small way, to a broader understanding of developments in medieval monasticism and to allow for comparison with other regions.

A first and tentative suggestion might be allowed here: In the overall perspective settlement patterns of the monastic islands in Ireland seem to follow the general settlement patterns in Ireland. A country with many islands and many island dwellers naturally produced a high number of island monks. Island monasticism in Ireland went hand in hand with mainland monasticism just as island settlement went hand in hand with mainland settlement. Lisa Bitel in her wonderful description of monastic settlement and Christian communities in Early Medieval Ireland made quite clear that monastic foundations were rarely settled far from clustered settlements. Even the stone cells of the western shores, once thought to be the solitary retreats of hermits, were actually quite close to friends and neighbourhoods. They seem isolated today only because they were built on the sea cliffs, and because the huts of their neighbours have now disappeared. She comes to the conclusion that, with very few exceptions, the monks thought accessible sites to be preferable and even strove to make their settlements easily accessible. ${ }^{23}$

We thus might conclude with Jenny White Marshall and Grellan Rourke, who in the course of their excavations on many of these monastic islands came to doubt what we might call the "splendid-isolation-theory" of medieval island monasticism. They suggest instead, that "the data does, however

21 Heraughty, Inishmurray, p. 29. Nevertheless, it is included as a female settlement here.

22 Madden, Holy Island, p. 22. For Irish nunneries see now the comprehensive survey of Collins, Isolated in the wilderness.

23 Bitel, Isle of the Saints, p. 37. 


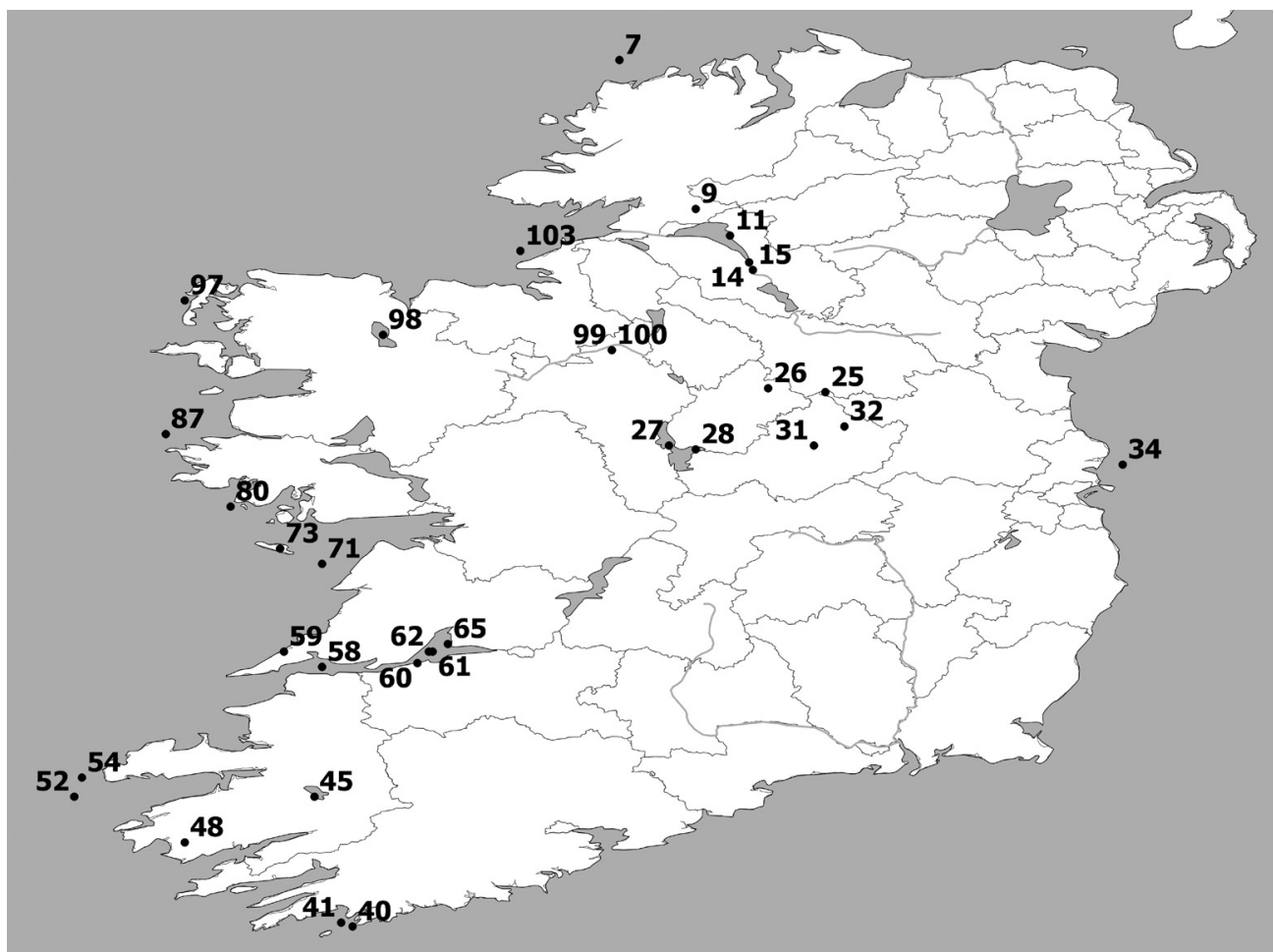

Map 2. Irish Island Monasteries connected with women

9 White Island

14 Devenish

17 Tory

19 Saints Island

22 Inishmurray

26 Saints Island

27 Inchcleraun

28 Inchmore

29 Nuns Island

32 Church Island

33 Inchmacnerin

34 Loughkey

38 Inishglora

44 Errew

48 Aran Islands Inishmore

49 Aran Islands Inisheer
59 Macdaras Island

60 Inishbofin

61 Inis-tuaischert

63 Bishops Island

65 Feenish

70 Island of Saints

71 Scattery

72 Inishloinge

76 Church Island

82 Inishtooskert

83 Inishvickillane

86 Innisfallen

90 Skeam Island West

91 Sherkin

96 Lambay

98 Lough Sheelin 
argue for a new perspective on island monasticism, one that views it as part of mainland monasticism rather than the earlier romantic image of a heroic quest for isolation and solitude. Instead it may be stated that island occupation, monastic or secular, was always an extension of the mainland culture, one that remained closely interwoven with it before and during the early medieval period." ${ }^{24}$

24 White Marshall/Rourke, Secular Origins, p. 34. 
Annexe 1: List of Medieval Religious Houses on Islands in Ireland ${ }^{25}$

Abbreviations:

GH = Gwynn, Aubrey/Hadcock, R. N., Medieval religious houses Ireland, London 1970. MH = Monasticon Hibernicum. Early Christian Ecclesiastical Settlement in Ireland

$5^{\text {th }}$ to $12^{\text {th }}$ Centuries. Database of the Monasticon Hibernicum Project by Ailbhe MacShamhráin with Nora White and Aidan Breen, under the direction of Kim McCone, Dublin 2003-2008.

Musther = Musther, John, Early Christian Sites in Ireland. Database, 2008-2014.

$\mathrm{e}=$ early site, possibly non-monastic, before 1100

$\mathrm{E}=$ Early Irish Monastery

$\mathbf{C}=$ Cistercians $/ \mathbf{A}=$ Augustinian Canons $/ \mathbf{B}=$ Benedictines $/$ OFM = Franciscan

Grey $=$ islands in inland waters.

The list follows the principles of Gwynn and Hadcock's Map of Monastic Ireland in the appendix of their Medieval Religious Houses (1970). It is ordered alphabetically. The figure in the last column of the table refers to the location of the site on the maps.

\begin{tabular}{|c|c|c|c|c|}
\hline $\begin{array}{l}\text { Monastic island, in alphabetical } \\
\text { order (with ref. to GH and } \mathrm{MH} \text { ) }\end{array}$ & Founder & Date & County & $\begin{array}{l}\text { Nr. } \\
\text { (map) }\end{array}$ \\
\hline $\begin{array}{l}\text { Aran Islands Inisheer, GH 373; } \\
\text { Ara Airthir MH; Cell Ghobnait on } \\
\text { Inisheer, Tempall na } 7 \text { n-Ingen on } \\
\text { Inisheer. MH }\end{array}$ & $\begin{array}{l}\text { Coeman / Colmán } \\
\text { mac Duagh } \dagger 632 \\
/ \text { Brecan } \uparrow 6^{\text {th }} \text { c. } / \\
\text { Gobnait } \dagger^{\text {th }} \text { c. } \\
\end{array}$ & e $6^{\text {th }} \mathrm{c}$. & Galway & 71 \\
\hline Aran Islands Inishmaan, GH 373 & Enda of Aran $† 530$ & e $6^{\text {th }} \mathrm{c}$. & Galway & 72 \\
\hline Aran Islands Inishmore, GH 28 & $\begin{array}{l}\text { Enda of Aran } \dagger 530 \\
\text { Brecan } \uparrow 6^{\text {th }} \text { cent } \\
\text { Soarney e. a. }\end{array}$ & e $6^{\text {th }} \mathrm{c}$. & Galway & 73 \\
\hline Ardmore ?, GH 29, 58, 62, 303 & $\begin{array}{l}\text { Declán of Ardmore } \\
\dagger 5^{\text {th }} \mathrm{c} \text {. }\end{array}$ & e $5^{\text {th }} c$. & Waterford & 38 \\
\hline $\begin{array}{l}\text { Beggerin Island (Becc Ériu), near } \\
\text { Slob Channel, MH }\end{array}$ & $\begin{array}{l}\text { Ibar of Beggerin } \\
\dagger 500\end{array}$ & $\mathrm{E}$ & Wexford & 36 \\
\hline Bishop’s Island, GH 374 & $\begin{array}{l}\text { Senán of Scattery } \\
\dagger 544\end{array}$ & $\mathrm{E} 6^{\text {th }} \mathrm{c}$. & Clare & 59 \\
\hline
\end{tabular}

25 I would like to express my thanks to Sophia Rishyna and Jonas Bruder for their support in the compilation of this list. We took over the spelling of the place names used by Gwynn and Hadcock. As to the location of the island monasteries in counties, we opted for the status quo: e. g. Inishbofin was part of County Mayo at the time of Gwynn and Hadcock. Today it belongs to County Galway. 


\begin{tabular}{|c|c|c|c|c|}
\hline $\begin{array}{l}\text { Monastic island, in alphabetical } \\
\text { order (with ref. to GH and } \mathrm{MH} \text { ) }\end{array}$ & Founder & Date & County & $\begin{array}{l}\text { Nr. } \\
\text { (map) }\end{array}$ \\
\hline $\begin{array}{l}\text { Boa Island, Lower Lough Erne, } \\
\text { Musther }\end{array}$ & $\begin{array}{l}\text { Constans? †777 } \\
\text { Caldragh? }\end{array}$ & $? 8^{\text {th }} \mathrm{c}$ & Fermanagh & 10 \\
\hline $\begin{array}{l}\text { Caher Island (Cathair-phadraig), } \\
\text { near Inishturk, GH } 375\end{array}$ & $\begin{array}{l}\text { Patrick } \uparrow 461 / 91 \\
\text { Colmán of } \\
\text { Lindisfarne } \uparrow 675\end{array}$ & e? & Mayo & 90 \\
\hline Cape Clear Island, GH 376 & $\begin{array}{l}\text { Ciarán the Elder } \\
\dagger \text { ca. } 530\end{array}$ & e? & Cork & 42 \\
\hline $\begin{array}{l}\text { Carrig Island, Shannon Estuary, GH } \\
\text { 364, MH }\end{array}$ & $?$ & $?$ & Kerry & 57 \\
\hline $\begin{array}{l}\text { Chapel Island off Clifden Bay }(= \\
\text { Oilén an Tempaill), } \mathrm{MH}\end{array}$ & $\begin{array}{l}\text { Caillin of Fenagh } \\
\dagger \text { around } 464\end{array}$ & $?$ & Galway & 83 \\
\hline $\begin{array}{l}\text { Chapel Island, Strangford Lough, } \\
\mathrm{MH}\end{array}$ & Cróine? & $\mathrm{E} ?$ & Down & 2 \\
\hline $\begin{array}{l}\text { Church Island, Lough Beg (Inis- } \\
\text { taiti), GH } 31\end{array}$ & $\begin{array}{l}\text { Toit? / Mochonna } \\
\text { (of Killyman? † 688) }\end{array}$ & $\mathrm{E} ?$ & Derry & 5 \\
\hline $\begin{array}{l}\text { Church Island, Lough Carra } \\
\text { (Rathen), GH } 401\end{array}$ & $\begin{array}{l}\text { Finan of Lindisfarne? } \\
\dagger 661 \text { ? / Finnian of } \\
\text { Clonard? } † 549\end{array}$ & e ? & Mayo & 94 \\
\hline $\begin{array}{l}\text { Church Island, Lough Currane } \\
\text { (Oilén an Tempaill), GH 31, MH }\end{array}$ & Finan Cam & $\mathrm{E} ?$ & Kerry & 48 \\
\hline $\begin{array}{l}\text { Church Island, Lough Gill (= Inis- } \\
\text { mor), GH } 31\end{array}$ & $\begin{array}{l}\text { Lommán mac Dalláin } \\
\dagger \text { early } 6^{\text {th }} c .\end{array}$ & $\mathrm{E} 6^{\text {th }} \mathrm{c}$. & Sligo & 102 \\
\hline $\begin{array}{l}\text { Church Island, Lough Kay, near } \\
\text { Valentia Island, GH } 376\end{array}$ & $?$ & e? & Kerry & 51 \\
\hline $\begin{array}{l}\text { Church Island, Lough Owel, GH } \\
\text { 376, } \mathrm{MH}\end{array}$ & $\begin{array}{l}\text { Lommán mac } \\
\text { Dalláin } † \text { early } 6^{\text {th }} c \text {. } \\
\text { / Carthage the Elder } \\
+6^{\text {th }} c \text {. }\end{array}$ & e ? & Westmeath & 31 \\
\hline Clare Island, GH 122, 129, 292, MH & St. Brigid? & $\begin{array}{l}\text { C? before } \\
1224\end{array}$ & Mayo & 91 \\
\hline $\begin{array}{l}\text { Cleenish Island, Lough Erne, GH } \\
31,277,303,347\end{array}$ & $\begin{array}{l}\text { Sinell mac Mianaig } \\
6^{\text {th }} \mathrm{c} .\end{array}$ & E. & Fermanagh & 17 \\
\hline $\begin{array}{l}\text { Croaghnakeela Island (= Cruagh na } \\
\text { Caíle), near Macdaras and Mason, } \\
\text { MH }\end{array}$ & $\begin{array}{l}\text { Coelan, monk from } \\
\text { Iniscaltra, Lough Ree }\end{array}$ & $E$ & Galway & 81 \\
\hline $\begin{array}{l}\text { Crump Island (= Oilén Dachruinne), } \\
\mathrm{MH}\end{array}$ & Rioch $\dagger$ after 490 & $?$ & Galway & 88 \\
\hline $\begin{array}{l}\text { Davy’s Island (Inishmore), Lower } \\
\text { Lough Erne, GH } 198\end{array}$ & $?$ & A ? & Fermanagh & 12 \\
\hline $\begin{array}{l}\text { Derrynane on Abbey Island, given } \\
\text { as Aghamore in GH 372; Achad } \\
\text { Mór/Daire Fhínáin, MH }\end{array}$ & Finan Cam, Bairre & $\begin{array}{l}\text { E } 7^{\text {th }} \text { c., } \\
\text { A? }\end{array}$ & Kerry & 47 \\
\hline
\end{tabular}




\begin{tabular}{|c|c|c|c|c|}
\hline $\begin{array}{l}\text { Monastic island, in alphabetical } \\
\text { order (with ref. to GH and } \mathrm{MH} \text { ) }\end{array}$ & Founder & Date & County & $\begin{array}{l}\text { Nr. } \\
\text { (map) }\end{array}$ \\
\hline $\begin{array}{l}\text { Devenish, Lower Lough Erne, GH } \\
33,153,169,362\end{array}$ & $\begin{array}{l}\text { Lasrén alias Molaise } \\
\dagger 564\end{array}$ & $\begin{array}{l}\text { E } \\
\text { A } 1130\end{array}$ & Fermanagh & 14 \\
\hline Dinish Island, $\mathrm{MH}$ & $?$ & $?$ & Kerry & 44 \\
\hline $\begin{array}{l}\text { Dunsy Island (given as Killinchy), } \\
\text { Strangford Lough, GH } 393\end{array}$ & Duinseach & e ? & Down & 3 \\
\hline $\begin{array}{l}\text { Duvillaun More (Dub Oilén), GH } \\
\text { 383, MH }\end{array}$ & $?$ & e ? & Mayo & 95 \\
\hline Enniskerry (Mutton Island), GH 383 & $\begin{array}{l}\text { Senán of Scattery } \\
\dagger 544\end{array}$ & E $6^{\text {th }} \mathrm{c}$. & Clare & 70 \\
\hline $\begin{array}{l}\text { Errew, Lough Conn, GH 36, 154, } \\
175,278,304,310,317\end{array}$ & $\begin{array}{l}\text { Tigernan of Errew } \\
\dagger \text { after } 520\end{array}$ & $\begin{array}{l}\text { E ? } \\
\text { A } 12^{\text {th }} \mathrm{c} .\end{array}$ & Mayo & 98 \\
\hline Feenish, Shannon Estuary, GH 384 & $\begin{array}{l}\text { Brigid of Kildare } \\
\dagger 525\end{array}$ & $\mathrm{E} 6^{\text {th }} \mathrm{c}$. & Clare & 65 \\
\hline Fenit Island, MH & $\begin{array}{l}\text { Brendan the } \\
\text { Navigator? } \dagger \text { ca. } 577\end{array}$ & & Kerry & 55 \\
\hline $\begin{array}{l}\text { Galloon Island, Upper Lough Erne } \\
\text { MH }\end{array}$ & Tighernach $† 549$ & e ? & Fermanagh & 20 \\
\hline Gorumna, GH 385 & $?$ & E ? & Galway & 77 \\
\hline $\begin{array}{l}\text { Great Blasket Island (Blascaod Mór), } \\
\text { one of the six Blasket Islands, MH }\end{array}$ & $?$ & $?$ & Kerry & 53 \\
\hline $\begin{array}{l}\text { Hare Island, Lough Ree, GH } \\
\text { 37, 154, } 177 \text { (also Inish Ainghin, } \\
\text { sometimes known as "Saints Island" } \\
\text { [not to be confused with Saints } \\
\text { Island, Co. Longford]) }\end{array}$ & $\begin{array}{l}\text { Ciarán the Younger } \\
\dagger 544\end{array}$ & E & Westmeath & 30 \\
\hline $\begin{array}{l}\text { High Island (= Ard-oilén), GH 386; } \\
\text { Ard Oilén/Cell Chóemáin, MH }\end{array}$ & $\begin{array}{l}\text { Féchín of Fore } \uparrow 665 \\
/ \text { Coeman }\end{array}$ & E & Galway & 85 \\
\hline $\begin{array}{l}\text { Illan Columbkille (Oilén Cholum } \\
\text { Cille), Lough Mask, MH }\end{array}$ & Columba $\uparrow 597$ & $?$ & Mayo & 92 \\
\hline $\begin{array}{l}\text { Illaunloughan, near Portmagee, GH } \\
386\end{array}$ & $?$ & E $7^{\text {th }} \mathrm{c}$. & Kerry & 49 \\
\hline Illaunmore, Lough Derg, GH 386 & ? & E $7-8^{\text {th }} \mathrm{c}$ & Clare & 67 \\
\hline Inchagoill, Lough Corrib, MH & $?$ & E & Galway & 76 \\
\hline Inchbofin, Lough Ree, GH 37, 199 & $\begin{array}{l}\text { Rioch } † \text { after } 490 / \\
\text { Áed mac Bricc } † 589\end{array}$ & E $5^{\text {th }}$ c.? & Westmeath & 29 \\
\hline $\begin{array}{l}\text { Inchcleraun, Lough Ree, called } \\
\text { Quaker Island, GH 37, 154, } 178\end{array}$ & Diarmaid the Just & E $6^{\text {th }} \mathrm{c}$. & Longford & 27 \\
\hline Inchicronan, GH 386, 154, 178 & $\begin{array}{l}\text { Cronan of } \\
\text { Tuamgraney, } 6^{\text {th }} c .\end{array}$ & E, A & Clare & 69 \\
\hline
\end{tabular}




\begin{tabular}{|c|c|c|c|c|}
\hline $\begin{array}{l}\text { Monastic island, in alphabetical } \\
\text { order (with ref. to GH and } \mathrm{MH} \text { ) }\end{array}$ & Founder & Date & County & $\begin{array}{l}\text { Nr. } \\
\text { (map) }\end{array}$ \\
\hline Inchiquin, Lough Corrib, GH 386 & $\begin{array}{l}\text { Brendan the } \\
\text { Navigator } † \text { ca. } 577\end{array}$ & $\begin{array}{l}\text { E before } \\
626\end{array}$ & Galway & 74 \\
\hline $\begin{array}{l}\text { Inchmacnerin, Lough Key, GH 386, } \\
154,179\end{array}$ & $?$ & E $6-7^{\text {th }} c$ & Roscommon & 100 \\
\hline $\begin{array}{l}\text { Inchmore, Lough Gowna, GH 37, } \\
154,179\end{array}$ & Columba $† 597$ & $\mathrm{E}, \mathrm{A}$ & Longford & 26 \\
\hline Inchydoney Island (Inis Dúine), $\mathrm{MH}$ & $?$ & $?$ & Cork & 39 \\
\hline Iniseo, Lower Lough Erne, GH 386 & Constans $† 777$ & $\mathrm{E}$ & Fermanagh & 18 \\
\hline Inishark, GH 386, MH & Leo of Inis Airc & $\mathrm{E} ?$ & Galway & 86 \\
\hline $\begin{array}{l}\text { Inishbofin, Knock parish, GH 386, } \\
\text { 199, } 109 \mathrm{MH} / \text { West Quarter, parish } \\
\text { (female) }\end{array}$ & $\begin{array}{l}\text { Colmán of } \\
\text { Lindisfarne } † 675 \text { / } \\
\text { Scaíthín }\end{array}$ & E 665 & Galway & 87 \\
\hline $\begin{array}{l}\text { Inishcaltra ( Holy Island), Lough } \\
\text { Derg, GH 37, 199, } 109\end{array}$ & $\begin{array}{l}\text { Colum mac } \\
\text { Crenthainn }(= \\
\text { Columba of } \\
\text { Terryglass }) \dagger 549 / \\
\text { Caimin } \dagger 654\end{array}$ & $\begin{array}{l}\text { E before } \\
658 ? \\
\text { B? }\end{array}$ & Clare & 66 \\
\hline Inishglora, GH 387 & $\begin{array}{l}\text { Brendan the } \\
\text { Navigator } \dagger \text { ca. } 577\end{array}$ & e & Mayo & 97 \\
\hline Inishkea North, GH 387 & $\begin{array}{l}\text { (church dedicated to) } \\
\text { Columba } † 597\end{array}$ & $\mathrm{E} ?$ & Mayo & 96 \\
\hline Inishkeel, GH 387 & Conall Cael & E $6^{\text {th }} \mathrm{c}$ & Donegal & 8 \\
\hline Inishkeen ( Inis-cain-dega), GH 37 & $\begin{array}{l}\text { Daig of Inniskeen } \\
\dagger 588(?)\end{array}$ & $\begin{array}{l}\mathrm{E} 6^{\text {th }} \\
\mathrm{A} 13^{\text {th }} \mathrm{c}\end{array}$ & Monaghan & 21 \\
\hline $\begin{array}{l}\text { Inishkeen, Lower Lough Erne, GH } \\
37\end{array}$ & $\begin{array}{l}\text { Mochoemoc / } \\
\text { Ninnidh } † 532\end{array}$ & E $6-7^{\text {th }} c$ & Fermanagh & 16 \\
\hline Inishloe, Shannon Estuary, GH 387 & $\begin{array}{l}\text { Turlogh, King of } \\
\text { Thomond / Senán of } \\
\text { Scattery? † } 544\end{array}$ & $\mathrm{E} ?$ & Clare & 64 \\
\hline $\begin{array}{l}\text { Inishloinge, near Scattery, GH } 387 \\
\text { (probably Foynes Island acc. to GH) }\end{array}$ & $\begin{array}{l}\text { Senán of Scattery } \\
\dagger 544\end{array}$ & $\mathrm{E} 6^{\text {th }} \mathrm{c}$. & Limerick & 60 \\
\hline Inishmacsaint, Lough Erne, GH 38 & Ninnidh $† 532$ & $\mathrm{E} 6^{\text {th }} \mathrm{c}$. & Fermanagh & 13 \\
\hline $\begin{array}{l}\text { Inishmicatreer, Lough Corrib, GH } \\
387\end{array}$ & $?$ & e? & Galway & 75 \\
\hline Inishmore (Deer Island?), GH 387 & $\begin{array}{l}\text { Senán of Scattery } \\
\dagger 544\end{array}$ & e $6^{\text {th }} \mathrm{c}$ & Clare & 63 \\
\hline Inishmore, Lough Arrow, GH 365 & $?$ & $?$ & Sligo & 101 \\
\hline Inishmurray, GH 387 & Molaise $† 564$ & $\mathrm{E}$ & Sligo & 103 \\
\hline $\begin{array}{l}\text { Inishnee, GH 387, now joint to the } \\
\text { Mainland }\end{array}$ & Martin or Matthias? & $\begin{array}{l}\text { e before } \\
768\end{array}$ & Galway & 82 \\
\hline
\end{tabular}




\begin{tabular}{|c|c|c|c|c|}
\hline $\begin{array}{l}\text { Monastic island, in alphabetical } \\
\text { order (with ref. to GH and } \mathrm{MH} \text { ) }\end{array}$ & Founder & Date & County & $\begin{array}{l}\text { Nr. } \\
\text { (map) }\end{array}$ \\
\hline $\begin{array}{l}\text { Inishtooskert, one of the six Blasket } \\
\text { Islands, GH } 387\end{array}$ & $\begin{array}{l}\text { ?Brendan the } \\
\text { Navigator } \dagger \text { ca. } 577\end{array}$ & e? & Kerry & 54 \\
\hline $\begin{array}{l}\text { Inishturk, near Caher Island, GH } \\
387,365\end{array}$ & $\begin{array}{l}\text { Colmán of } \\
\text { Lindisfarne } \dagger 675 \text { ? }\end{array}$ & E $7^{\text {th }} \mathrm{c}$. & Mayo & 89 \\
\hline $\begin{array}{l}\text { Inishvickillane, one of the six Blasket } \\
\text { Islands, GH } 387\end{array}$ & $\begin{array}{l}\text { ?Brendan the } \\
\text { Navigator } \dagger \text { ca. } 577\end{array}$ & e? & Kerry & 52 \\
\hline $\begin{array}{l}\text { Inis-tuaischert (in the Fergus } \\
\text { estuary, maybe Inishtubbrid?), GH } \\
388\end{array}$ & $\begin{array}{l}\text { Senán of Scattery } \\
\dagger 544\end{array}$ & e $6^{\text {th }} \mathrm{c}$. & Clare & 62 \\
\hline $\begin{array}{l}\text { Innisfallen, Lough Leane, GH 38, } \\
154,180,304,351\end{array}$ & $\begin{array}{l}\text { Faithleann / Finan } \\
\text { Lobhair (= Finian } \\
\text { the Leper) }+560\end{array}$ & $\begin{array}{l}\text { E } 640 / \\
\text { A } 13^{\text {th }} \mathrm{c} .\end{array}$ & Kerry & 45 \\
\hline Ireland's Eye, GH 388 & $?$ & e? & Dublin & 35 \\
\hline $\begin{array}{l}\text { Canon Island (Island of Saints), GH } \\
375,153,162\end{array}$ & $\begin{array}{l}\text { Senán of Scattery } \\
\dagger 544\end{array}$ & $\begin{array}{l}\text { e } 6^{\text {th }} \mathrm{c} . \\
/ \mathrm{A}\end{array}$ & Clare & 61 \\
\hline $\begin{array}{l}\text { Kilcummin, north of Aran Island, } \\
\text { Lettermullen, west of Gorumna, } \\
\text { GH } 390\end{array}$ & Coeman & e ? & Galway & 78 \\
\hline $\begin{array}{l}\text { Lady's Island, Vogue's on Lady's } \\
\text { Island, GH 199, 304; MH; MH }\end{array}$ & $\begin{array}{l}\text { Ibar of Beggerin? } \\
\dagger 500 / \text { Beóc }\end{array}$ & $\mathrm{E} ? / \mathrm{A}$ & Wexford & 37 \\
\hline Lambay, GH 396 & Columba $† 597$ & e ? & Dublin & 34 \\
\hline $\begin{array}{l}\text { Lough Sheelin = Inis Uachtair on } \\
\text { Church Island in Lough Sheelin, } \\
\text { GH } 397,367\end{array}$ & $\begin{array}{l}\text { Carthach the Elder? } \\
\text { (Mo Chuta) } \dagger 6^{\text {th }} \text { c. }\end{array}$ & $\begin{array}{l}\mathrm{e} \\
\text { Friary? }\end{array}$ & Meath & 25 \\
\hline $\begin{array}{l}\text { Trinity in Loughkey, GH 203, 205, } \\
397\end{array}$ & $?$ & e, A 1140 & Roscommon & 99 \\
\hline $\begin{array}{l}\text { Illauntannig,on Magharee Is., GH } \\
386\end{array}$ & Seanach $† 620$ & E $6-7^{\text {th }} \mathrm{c}$. & Kerry & 56 \\
\hline Magheracross, GH 398, 354 & Patrick? † 461/91 & e ? & Fermanagh & 19 \\
\hline $\begin{array}{l}\text { Mason Island (= Oilén Maisean), } \\
\text { MH neighbouring Macdaras Island }\end{array}$ & & $?$ & Galway & 79 \\
\hline Mucinis, Lough Derg, GH 399 & Columba? †597 & e ? & Clare & 68 \\
\hline $\begin{array}{l}\text { Nendrum, Strangford Lough, GH } \\
42,104,107\end{array}$ & $\begin{array}{l}\text { Mochae / Patrick } \\
\dagger 461 / 91\end{array}$ & e ? & Down & 1 \\
\hline Nun’s Island, Lough Ree, MH & $?$ & $?$ & Westmeath & 32 \\
\hline $\begin{array}{l}\text { Omey Island, near Claddaghduff, } \\
\text { GH } 400\end{array}$ & Féchín of Fore $† 665$ & e $7^{\text {th }} \mathrm{c}$. & Galway & 84 \\
\hline $\begin{array}{l}\text { Partry, between Lough Mask and } \\
\text { Lough Carra, GH } 400\end{array}$ & $?$ & e ? & Mayo & 93 \\
\hline Rams Island, Lough Neagh, GH 401 & ? & e ? & Antrim & 4 \\
\hline
\end{tabular}




\begin{tabular}{|c|c|c|c|c|}
\hline $\begin{array}{l}\text { Monastic island, in alphabetical } \\
\text { order (with ref. to GH and } \mathrm{MH} \text { ) }\end{array}$ & Founder & Date & County & $\begin{array}{l}\text { Nr. } \\
\text { (map) }\end{array}$ \\
\hline Rathlin Island, GH 401 & Ségéne of Iona $† 652$ & e 635 & Antrim & 6 \\
\hline Rossory, GH 402, 355 & Fanchea, $6^{\text {th }} \mathrm{c}$ & e & Fermanagh & 15 \\
\hline $\begin{array}{l}\text { Saggart on St. Patrick's Island, GH } \\
403\end{array}$ & Mosacra / Patrick? & e ? & Dublin & 33 \\
\hline $\begin{array}{l}\text { Saints Island and Station Island (= } \\
\text { St. Patrick's Purgatory), Lough Derg, } \\
\text { GH 44, 155, } 193\end{array}$ & Patrick $\dagger 461 / 91$ & $\mathrm{E} ? / \mathrm{A}$ & Donegal & 9 \\
\hline $\begin{array}{l}\text { Saints Island, Lough Ree, GH 155, } \\
\text { 193, 304, } 403 \text { / Inis na Náem, MH }\end{array}$ & $\begin{array}{l}\text { Ciarán † ca. } 549 \\
\text { Donnán of Eigg } \\
\dagger 617\end{array}$ & $\begin{array}{l}\text { e before } \\
542 \text { / A }\end{array}$ & Longford & 28 \\
\hline Scariff, GH 403 & early anchorite site & e? & Kerry & 46 \\
\hline $\begin{array}{l}\text { Scattery Island, Shannon Estuary, } \\
\text { GH } 44,59,96,359,361\end{array}$ & $\begin{array}{l}\text { Senán of Scattery } \\
\dagger 544\end{array}$ & $\mathrm{E} 6^{\text {th }} \mathrm{c}$. & Clare & 58 \\
\hline $\begin{array}{l}\text { Sherkin Island (Inis-arcain), GH } \\
241,258\end{array}$ & Fineen O’Driscoll & $\begin{array}{l}\text { OFM } \\
1460 / 62\end{array}$ & Cork & 40 \\
\hline Skeam Island West, GH 404 & $?$ & e? & Cork & 41 \\
\hline Skellig Michael, GH 404 & $\begin{array}{l}\text { Finnian of Inis- } \\
\text { Conla? }\end{array}$ & e $6^{\text {th }} \mathrm{c}$. & Kerry & 50 \\
\hline St. Macdara’s Island, GH 403 & (Sionnach) Mac Dara & e ? & Galway & 80 \\
\hline $\begin{array}{l}\text { St. Mogue's Island (Inis Brechmaige), } \\
\text { Templeport Lough, MH }\end{array}$ & Mogue $† 632$ & E & Cavan & 22 \\
\hline Tory Island, GH 46 & Columba $† 597$ & $\mathrm{E} 6^{\text {th }} \mathrm{c}$. & Donegal & 7 \\
\hline Trinity Island, Lough Oughter, $\mathrm{MH}$ & $?$ & $?$ & Cavan & 23 \\
\hline $\begin{array}{l}\text { Whiddy Island off Bantry Bay: Cell } \\
\text { Mór (Kilmore), MH }\end{array}$ & $?$ & $?$ & Cork & 43 \\
\hline White Island, Lower Lough Erne & $?$ & A? $12^{\text {th }} \mathrm{c}$ & Fermanagh & 11 \\
\hline $\begin{array}{l}\text { Woodworths/Woodward's Island, } \\
\text { Lough Ramor, MH }\end{array}$ & $\begin{array}{l}\text { Patrick / Brandub } \\
\text { mac Fiachrach }\end{array}$ & $\begin{array}{l}\mathrm{E} ? / \mathrm{A} \\
13^{\text {th }} \mathrm{c} .\end{array}$ & Cavan & 24 \\
\hline
\end{tabular}




\section{Bibliography}

Archdall, Mervyn, Monasticon Hibernicum or A history of the Abbies Priories and Other Religious Houses in Ireland, Dublin 1786.

Bitel, Lisa M., Isle of the Saints. Monastic Settlement and Christian Community in Early Ireland, New York 1990.

Chambers, Richard, White Island. History and Mystery (Erne Heritage Tour Guides) 2002.

Collins, Tracy, Isolated in the wilderness? An archaeological exploration of nunneries in the medieval landscape of Ireland, in: James LytTLETon/Matthew STOut (ed.), Church and Settlement in Ireland, Dublin 2018, p. 142-156.

Cotter, Claire, Western Stone Forts (Dún Eoghanachta, Inis Mór, Co. Galway and Dún Aonghasa, Inis Mór, Co. Galway), The Heritage Councel. Significant Unpublished Irish Archaeological Excavations, 1930-1997. Section 11. http://www.heritagecouncil. ie/unpublished_excavations/section11.html.

Crowley, John, Valentia Island, in: Crowley, John/Sheehan, John/Murphey, Mike (ed.), The Iveragh Peninsula. A Cultural Atlas of the Ring of Kerry, Cork 2009, 260-265.

$\mathrm{GH}=$ Gwynn, Aubrey /Hadcock, R. Neville, Medieval Religious Houses in Ireland, London 1970.

Heraughty, Patrick, Inishmurray. Ancient Monastic Island, Dublin 1982.

Horn, Walter/White Marshall, Jenny/Rourke, Grellan D., The Forgotten Hermitage of Skellig Michael, Berkeley 1990.

Kehnel, Annette, Clonmacnois - the Church and Lands of St Ciarán. Change and Continuity in an Irish Monastic Foundation ( $6^{\text {th }}$ to $16^{\text {th }}$ centuries), Münster 1997.

Madden, Gerard, Holy Island. Inis Cealtry. Island of the Churches, Mountshannon 2008.

$\mathrm{MH}=$ Monasticon Hibernicum. Early Christian Ecclesiastical Settlement in Ireland $5^{\text {th }}$ to $12^{\text {th }}$ Centuries. Database of the Monasticon Hibernicum Project by Ailbhe MacShamhráin with Nora White and Aidan Breen, under the direction of Kim McCone, Dublin 2003-2008. https://monasticon.celt.dias.ie 30.01.2018.

Musther, John, Early Christian Sites in Ireland. Database by Fr John Musther, 2008-2014. http://www.earlychristianireland.net 30.01.2018.

Power, P., Life of St Declan of Ardmore (Irish Text Society 20), London 1914.

Rourke, D. Grellan/Skellig Michael, Monastic Island Retreat in the Atlantic, in: Crowley, John/Sheehan, John/Murphey, Mike (ed.), The Iveragh Peninsula. A Cultural Atlas of the Ring of Kerry, Cork 2009, p. 129-135.

STokes, George T., The Island Monasteries of Wales and Ireland, in: The Journal of the Royal Society of Antiquaries of Ireland 1, Nr. 8 (1891), p. 658-664.

Tном, Catherine, Early Irish monasticism. An Understanding of its Cultural Roots, London 2006.

White Marshall, Jenny/Rourke, Grellan D., The Secular Origins of the Monastic Enclosure Wall of High Island, Co. Galway, in: Archaeology Ireland 14,2 (2000), S. 30-34.

White Marshall, Jenny/Walsh, Claire, Unpublished Excavations Report 12.6 Illaunloughan. Co. Kerry, in: Significant Unpublished Irish Archaeological Excavations 1930-97, Heritage Council, University College Cork 19E180 http://www.heritagecouncil.ie/unpublished_excavations/section12.html\#Iniscealtra. 30.01.2018. 